\title{
STUDI INDEKS VEGETASI UNTUK IDENTIFIKASI VEGETASI HUTAN GAMBUT MENGGUNAKAN CITRA AIRBORNE HYPERSPECTRAL HYMAP DI DAERAH HUTAN GAMBUT KALIMANTAN TENGAH
}

\author{
Rizky Andianto, Hepi Hapsari Handayani \\ Program Studi Teknik Geomatika FTSP-ITS, Kampus ITS Sukolilo, Surabaya, 60111 \\ Email : hapsari@geodesy.its.ac.id
}

\begin{abstract}
Abstrak
Tujuan dari penelitian ini adalah untuk menghitung nilai indeks vegetasi serta mencari indeks vegetasi yang paling baik dalam rangka pembuatan peta kerapatan vegetasi hutan gambut Kabupaten Katingan dan Kabupaten Pulang Pisau,Kalimantan Tengah. Peta tersebut berguna untuk mengidentifikasi vegetasi hutan gambut.

Metode indeks vegetasi yang digunakan adalah NDVI, RDVI, dan MSR dengan menggunakan panjang gelombang ( $750,705)$ dan $(800,670$ ) yang dikorelasikan dengan data prosentase crown cover. Selanjutnya perhitungan algoritma dengan koefisien korelasi terbaik yang akan digunakan untuk menghasilkan peta persebaran crown cover. Lokasi

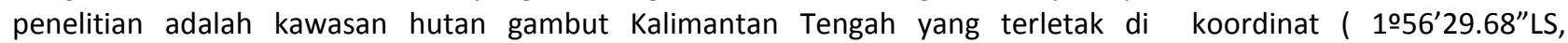

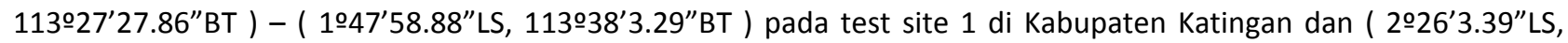
11351'13.42"BT ) - ( 214'13.55”LS, 114ㅇㄱ'38.41”BT ) pada test site 2 di Kabupaten Pulang Pisau.
\end{abstract}

Hasil penelitian ini menunjukkan bahwa citra Airborne Hyperspectral Hymap mampu digunakan dalam menghasilkan data indeks vegetasi dengan algoritma NDVI, RDVI, dan MSR. Nilai koefisien determinasi tertinggi 0,821 yaitu dengan indeks vegetasi NDVI pada panjang gelombang ( 750,705) kerapatan crown cover yang dihasilkan menjadi 6 kelas yaitu sangat rapat ( $85-100 \%)$, rapat ( $70-84 \%$ ), sedang ( $50-69 \%$ ), rendah ( 30-49\% ), jarang ( $10-29 \%$ ), sangat jarang (1-9\% ). Kecuali NDVI pada panjang gelombang ( 800,670), crown cover dapat memiliki efek yang besar pada indeks vegetasi yang diikuti dengan besarnya koefisien determinasi yaitu $\operatorname{MSR}_{(750,700)}=0.798, \operatorname{RDVI}_{(750,705)}=0.541, \mathrm{RDVI}_{(800,670}$ $=0.678, \operatorname{NDVI}_{(800,670)}=0.305, \operatorname{NDVI}_{(750,705)}=0.821$

Hasil klasifikasi dari Peta Kerapatan Vegetasi digunakan untuk analisa kesesuaian terhadap UU RKTN 2011 - 2030, yang hasilnya adalah pada test site 1 terdapat $0.002 \%$ dari vegetasi yang termasuk dalam kawasan hutan alam dan lahan gambut, $0.067 \%$ termasuk dalam kawasan pengusahaan skala kecil, dan $2.883 \%$ termasuk dalam kawasan perusahaan skala besar (HA/HT). Namun pada test site $284 \%$ vegetasi termasuk pada kawasan konservasi dan sisanya tidak termasuk dalam kawasan arahan kebijakan.

Kata kunci: Hutan Gambut, Indeks Vegetasi, Citra Hymap

\section{PENDAHULUAN}

Salah satu isu global yang sedang marak diperbincangkan di dunia sekarang adalah isu tentang pemanasan global dan adanya gas rumah kaca ( greenhouse gases ). Pada bulan September tahun 2009 Presiden Susilo Bambang Yudhoyono memberikan pernyataan pada puncak G-20 di Pittsburgh (Amerika Serikat) yaitu mengurangi gas rumah kaca (greenhouse gases) sebesar 26\% melalui National Appropriate Mitigation and Adaptation (NAMA) hingga tahun 2020 dan menjadi $40 \%$ dengan bantuan internasional. Dalam menanggapi hal tersebut banyak penelitian dilakukan dan diupayakan untuk mendeteksi adanya kandungan karbon dan untuk meneliti gas rumah kaca yang sudah dihasilkan dari hutan primer dan lahan gambut di Indonesia. Salah satunya penelitian yang dilakukan oleh Ohki Takahashi dkk untuk mendiagnosa degradasi hutan gambut di Kalimantan Tengah dengan menggunakan indeks vegetasi Normalized Difference Water Index (NDWI) dan Water Band Index (WBI) (Takahashi dkk, 2012). Dan juga penelitian Edita Yudia tahun 2000 tentang studi indeks vegetasi untuk identifikasi vegetasi hutan rawa gambut melalui analisis digital data landsat TM dengan menggunakan indeks vegetasi NDVI, RVI, GVI, BVI, dan WVI dan dengan menggunakan data canopy cover untuk dikorelasikan dengan data hasil indeks vegetasi, studi kasus di sebagian areal HPH PT. Brata Jaya Utama, Kalimantan 
Tengah. Canopy cover dapat diartikan sebagai crown closure, canopy closure, atau crown cover yang juga objek dari penelitian ini (T.E. Avery dan H.E.Burkhart, 2002).

Penggunaan penginderaan jauh yang banyak digunakan adalah penginderaan jauh multispectral dengan berbagai kelebihannya. Namun teknologi penginderaan jauh yang sebenarnya mempunyai lebih banyak keuntungan adalah teknologi penginderaan jauh Hyperspectral. Selain dengan jumlah bandnya yang sangat banyak, penginderaan jauh Hyperspectral juga memiliki resolusi spasial yang sangat baik digunakan untuk keperluan analisa di berbagai bidang keilmuan, salah satunya pada penelitian di bidang vegetasi. Karena penginderaan jauh Hyperspectral lebih memiliki banyak keunggulan daripada penginderaan jauh Multispectral, maka perlu dilakukan penelitian untuk masalah studi indeks vegetasi melalui penginderaan jauh Hyperspectral sehingga manfaatnya dapat digunakan dengan baik untuk penelitian yang lebih lanjut terhadap indeks vegetasi dan identifikasi terhadap adanya vegetasi, khususnya untuk daerah hutan rawa gambut.

\section{METODOLOGI PENELITIAN}

\section{A. Lokasi Penelitian}

Lokasi pada penelitian adalah kawasan hutan gambut Kabupaten Katingan dan Kabupaten Pulang Pisau, Kalimantan Tengah yang terletak di koordinat (1056'29.68"LS, 11327'27.86"BT) (1947'58.88'LS, 11338'3.29"BT) pada test site 1 dan (226'3.39"LS, 11351'13.42"BT) (214'13.55"LS, 114ㅇ'38.41"BT) pada test site 2 .

\section{B. Data dan Perangkat Lunak}

Data yang digunakan dalam penelitian ini adalah Citra Hymap Hutan gambut Kalimantan Tengah yang diambil pada 15 dan 16 Juli 2011 . Data non spasial berupa data survai lapangan yang menghasilkan data prosentase crown cover, dan data sekunder (literatur dari instansi terkait). Data crown cover diambil menggunakan kamera fisheye di pusat dari setiap $10 \mathrm{~m}$ subquadrat.

Perangkat lunak untuk analisis persentase vegetasi menggunakan analysis tools pada Arc.Gis
9. Struktur data SIG yang digunakan adalah struktur data raster dengan pixel $4.5 \mathrm{~m}$.

\section{Hutan Gambut}

Hutan gambut juga biasa disebut dengan hutan rawa gambut karena istilah hutan rawa dan hutan gambut yang umumnya berdekatan, seringkali tidak memiliki batas yang tegas. Ciri umum tanah gambut, tidak mengalami perkembangan profil ke arah terbentuhya horizon-horizon yang berbeda, berwama coklat kelam sampai hitam, berkadar air tinggi dan berwama seperti teh serta bereaksi masam dengan pH 3,0 - 5,0 (Istomo, 1992).

Menurut Jacobs (1988), hutan rawa gambut adalah salah satu tahap suksesi dari hutan rawa dimana memiliki $\mathrm{pH}$ rendah, miskin mineral dan tingkat dekomposisi alami yang rendah. Pada beberapa wilayah terdapat hutan rawa gambut yang dipengaruhi oleh air sungai sehingga terdapat dekomposisi bahan organik yang tinggi.

\section{Deskripsi Crown Cover}

Crown cover atau biasa disebut dengan crown closure, canopy cover, atau canopy closure dapat diartikan sebagai persen dari kanopi di atas lantai hutan. Pengertian lain dari crown cover adalah proporsi dari suatu tegakan ditutupi oleh tajuk pohon hidup. Crown cover membantu memprediksi volume, kerapatan tegakan, lebar tajuk dan faktor kompetisi tajuk.

Indeks vegetasi berkorelasi kuat dengan klorofil atau canopy nitrogen sehingga memungkinkan untuk mengidentifikasi canopy metrics seperti leaf area atau tutupannya secara penginderaan jauh ( Burak P. dan Craig M., 2009 ). Maka dari itu, penelitian ini menggunakan crown cover sebagai validator dari indeks vegetasi.

\section{E. Deskripsi Citra Hymap}

Kata "Hymap" adalah singkatan dari Hyperspectral Mapper merupakan suatu merek dagang untuk suatu instrumen khusus di bidang penginderaan jauh dengan wahana pesawat terbang. Sensor hiperspektral wahana pesawat terbang ini dikembangkan oleh Australia dan sekarang telah banyak digunakan oleh negaranegara di seluruh dunia dalam berbagai aplikasi. Sensor Hymap memiliki region spectral 
yaitu pada visible, Near Infra Red ( NIR ), Jumlah kanal 100-200, spectral bandwidth $10-20 \mathrm{~nm}$, resolusi spasial 2 - $10 \mathrm{~m}$, swath width $60-70$ derajat.

\section{E. Prosedur Penelitian}

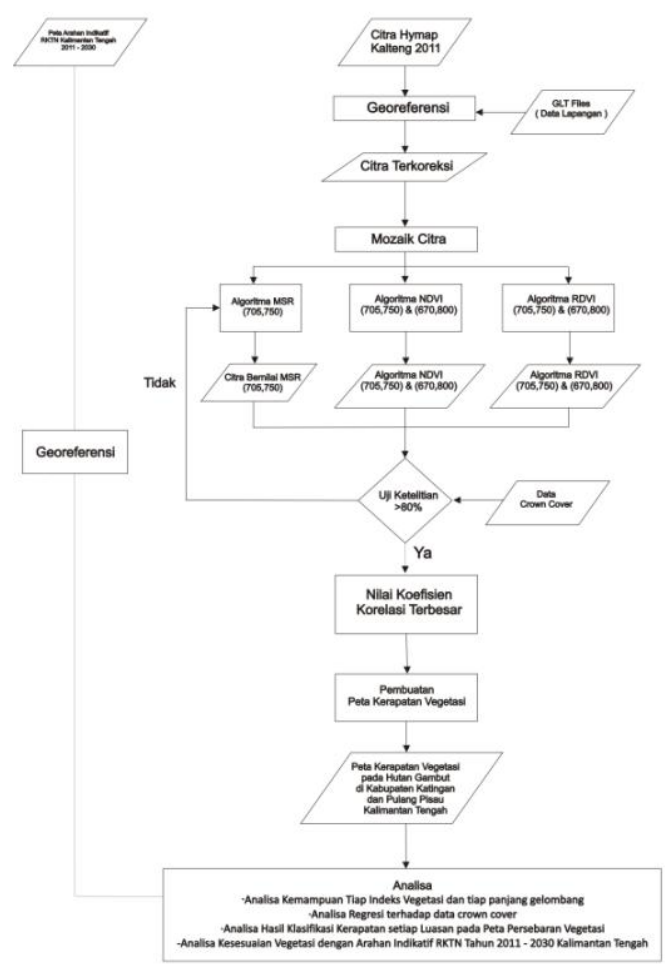

Gambar 1. Flowchart metodologi penelitian

Sebelum diolah dengan menggunakan algoritma indeks vegetasi, citra Hymap perlu melewati proses georeferencing dan koreksi geometrik.

Pada penelitian ini proses georeferencing menggunakan Georeference from GLT dengan menggunakan data berformat (.bsq) . Pada tahap ini menggunakan file IGM (Input Geometry) yang dibuat dalam bentuk table atau biasa disebut dengan file GLT (Geometric Lookup Table). Metode ini adalah metode georeferencing data yang paling akurat karena setiap pixelnya diberikan nilai lokasi peta. Setelah itu melakukan koreksi geometrik dengan menggunakan citra Hymap yang telah terkoreksi geometrik.

Dalam penelitian ini citra Hymap pada setiap lajur tersebut perlu dilakukan penggabungan untuk mendapatkan citra mosaik. Hal ini diperlukan untuk dapat menganalisa daerah satu kawasan tersebut secara keseluruhan. Syarat dilakukan mozaiking citra keempat tersebut harus sudah terkoreksi.

Penelitian ini menggunakan 3 Indeks vegetasi yaitu NDVI (Normalized difference Vegetation Index), RDVI ( Renormalized Vegetation Index), dan MSR (Modified Simple Ratio).
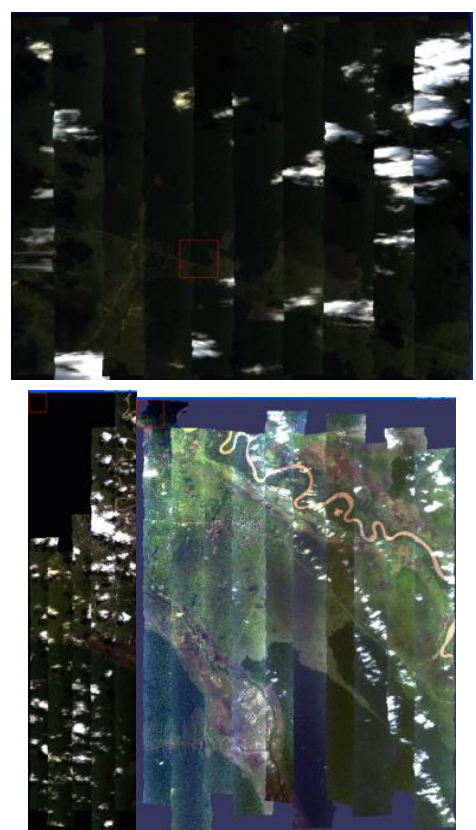

Gambar 2. Hasil Mosaicking pada test site 1 \& 2

\section{F. NDVI ( Normalized Difference Vegetation Index)}

Indeks vegetasi adalah besaran nilai kehijauan vegetasi yang diperoleh dari pengolahan sinyal dijital data nilai kecerahan (brightness) beberapa kanal sensor satelit. Untuk pemantauan vegetasi, dilakukan proses pembandingan antara tingkat kecerahan kanal cahaya merah (red) dan kanal cahaya inframerah dekat (near infrared).

Fenomena penyerapan cahaya merah oleh klorofil dan pemantulan cahaya infaramerah dekat oleh jaringan mesofil yang terdapat pada daun akan membuat nilai kecerahan yang diterima sensor satelit pada kanal-kanal tersebut akan jauh berbeda. Pada daratan non-vegetasi, termasuk diantaranya wilayah perairan, pemukiman penduduk, tanah kosong terbuka, dan wilayah dengan kondisi vegetasi yang rusak, tidak akan 
menunjukkan nilai rasio yang tinggi (minimum). Sebaliknya pada wilayah bervegetasi sangat rapat, dengan kondisi sehat, perbandingan ke dua kanal tersebut akan sangat tinggi (maksimum).

Algoritma Normalized difference Vegetation Index (NDVI) (Rouse et al., 1974) adalah :

$$
\frac{\text { Band } 1-\text { Band } 2}{\text { Band } 1+B a n d 2}=N D V I
$$

Keterangan :

Band $1=$ band near infra red

Band 2 = bandred

Indeks vegetasi berbasis NDVI mempunyai nilai yang hanya berkisar antara -1 (non-vegetasi) hingga +1 (vegetasi). Nilai NDVI yang rendah (negatif) menunjukkan tingkat vegetasi yang rendah seperti awan, air, tanah kosong, bangunan, dan unsur non-vegetasi lainnya. Sedangkan nilai NDVI yang tinggi (positif) menunjukkan tingkat vegetasi hijau yang tinggi. Jadi, nilai NDVI sebanding dengan kuantitas tutupan vegetasinya.

Pada penggunaan hyperspectral gelombang sempit indeks ini dapat dituliskan dalam persamaan berikut ( Rouse et al, 1974 ):

$$
\text { NDVI }[670,800]=\frac{\text { Band } 800-\text { Band } 670}{\text { Band } 800+\text { Band } 670}
$$

Keterangan :

$$
\begin{array}{ll}
\text { Band } 800 & =\text { band near infra red } \\
\text { Band } 670 & =\text { band red }
\end{array}
$$

Kemudian Gitelson dan Merzlyak (1994) mendapatkan nilai NDVI yang berbeda pada panjang gelombang $705 \mathrm{~nm}$ dan $750 \mathrm{~nm}$ untuk mendapatkan nilai yang lebih efektif yang dirumuskan pada persamaan berikut ini :

$$
\text { NDVI }[705,750]=\frac{\text { Band } 750-\text { Band } 705}{\text { Band } 750+\text { Band } 705}
$$

Keterangan :

Band $750=$ band near infra red

Band $705=$ band red

\section{G. RDVI (Renormalized Difference Vegetation Index)}

RDVI dikembangkan untuk melinierisasikan hubungannya dengan variable fisik dari suatu vegetasi. Tujuan dari RDVI sendiri adalah untuk mengkombinasi manfaat dari Difference vegetation Index (DVI = NIRRed) dan NDVI untuk nilai LAI tinggi dan rendah. RDVI kurang sensitive terhadap klorofil daripada NDVI. (Driss Haboudane et al, 2003 ). Persamaannya adalah berikut ini :

$$
R D V I=\frac{(\rho N I R-\rho R e d)}{\sqrt{(\rho N I R+\rho R e d)}}(4)
$$

Sehingga :

$$
R D V I=\frac{(R 800-R 670)}{\sqrt{(R 800+R 670)}}(5)
$$

Keterangan :

Band $800=$ band near infra red

Band $670=$ band red

Sumber : ( Jordan, 1969)

\section{F. MSR (Modified Simple Ratio )}

MSR telah disarankan sebagai perbaikan dari RDVI dalam hal sensitivitas pada parameter biofisik vegetasi melalui kombinasinya dengan simple ratio $(S R=N I R /$ Red). MSR merupakan indeks yang paling berpengaruh terhadap variable klorofil daripada NDVI dan MSR ( Driss Haboudane et al, 2003 ). Persamaannya adalah berikut ini :

$$
M S R=\frac{\left(\frac{\rho N I R}{\rho \operatorname{Red}}-1\right)}{\sqrt{\frac{\rho N I R}{\rho \operatorname{Red}}}+1}
$$

Keterangan :

Band $800=$ band near infra red

Band $670=$ band red

Sumber : (Jordan, 1969) 
Lalu, dilakukan proses analisis regresi untuk mencari hubungan antara nilai indeks vegetasi dengan persentase crown cover, nilai koefisien korelasi terbesar yang dihasilkan digunakan sebagai persamaan untuk menghasilkan peta kerapatan vegetasi di wilayah hutan gambut Kabupaten Katingan dan Pulang Pisau,Kalimantan Tengah. Setelah itu dilakukan analisa berdasarkan dari data yang dihasilkan. Salah satunya ialah analisa dengan peta arahan indikatif RKTN Kalimantan Tengah 2011-2030 sehingga akan didapatkan analisa kesesuaian vegetasi.

\section{HASIL DAN PEMBAHASAN}

A. Hasil Indeks Vegetasi

Indeks Vegetasi NDVI pada panjang gelombang 705 - $750 \mathrm{~nm}$ menghasilkan keakurasian hubungan yang lebih baik dibandingkan metode NDVI pada panjang gelombang $670-800 \mathrm{~nm}$, MSR pada panjang gelombang $705-750 \mathrm{~nm}$, dan RDVI pada panjang gelombang $705-750 \mathrm{~nm}$ dan $670-800 \mathrm{~nm}$ dimana koefisien determinasi dari metode NDVI pada panjang gelombang $705-750$ $\mathrm{nm}$ adalah 0.821 .

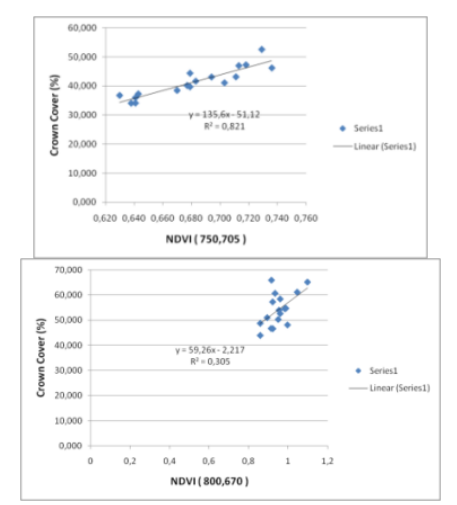

Gambar 3. Kurva Hasil Regresi antara NDVI ( 750,705 ) dan NDVI ( 800,670) dengan Data Prosentase Crown Cover

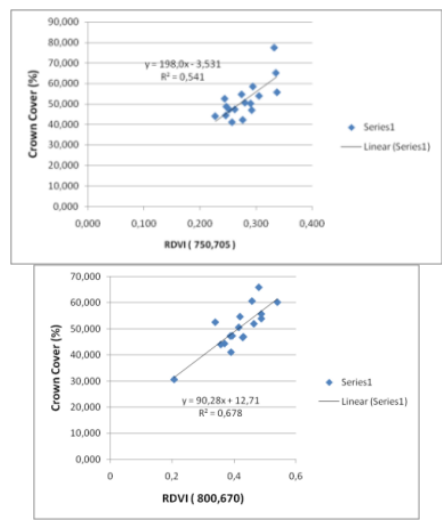

Gambar 4. Kurva Hasil Regresi antara RDVI ( 750,705 ) dan RDVI ( 800,670 ) dengan Data Prosentase Crown Cover



Gambar 5. Kurva Hasil Regresi antara MSR ( 750,705) dengan Data Prosentase Crown Cover

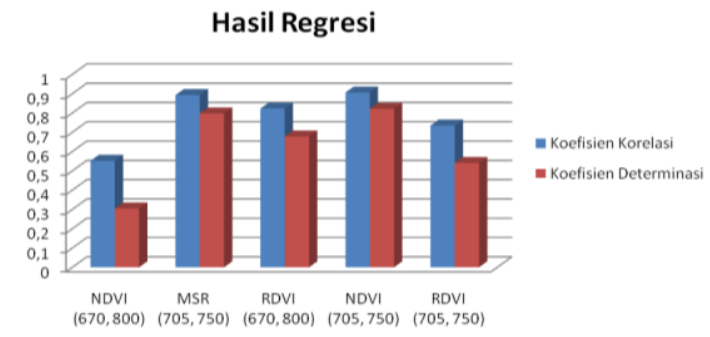

Gambar 6 Grafik Batang Hasil Regresi Nilai Indeks Vegetasi dan Data Crown Cover

Tabel 1. Hasil regresi indeks vegetasi dan data crown cover

\begin{tabular}{cccc}
\hline \hline $\begin{array}{c}\text { Parameter } \\
(\mathrm{X})\end{array}$ & Hasil Regresi & $\begin{array}{c}\text { Koefisien } \\
\text { Determinasi }\left(\mathrm{R}^{2}\right)\end{array}$ & $\begin{array}{c}\text { Koefisien } \\
\text { korelasi }\end{array}$ \\
& & & $(\mathrm{R})$ \\
\hline $\begin{array}{c}\text { NDVI (670, } \\
800)\end{array}$ & $\begin{array}{c}\mathrm{Y}=59,26 \mathrm{x}- \\
2,217\end{array}$ & 0.305 & 0.552 \\
$\mathrm{MSR}(705$, & $\mathrm{Y}=24,95 \mathrm{x}$ & & \\
$750)$ & 0,113 & 0.798 & 0.893 \\
$\mathrm{RDVI}(670$, & $\mathrm{Y}=90,28 \mathrm{x}+$ & 0,678 & \\
$800)$ & 12,71 & & 0.823 \\
\hline
\end{tabular}




\begin{tabular}{|c|c|c|c|}
\hline $\begin{array}{l}\text { Parameter } \\
\qquad(\mathrm{X})\end{array}$ & Hasil Regresi & $\begin{array}{c}\text { Koefisien } \\
\text { Determinasi }\left(R^{2}\right)\end{array}$ & $\begin{array}{c}\text { Koefisien } \\
\text { korelasi } \\
\text { (R) }\end{array}$ \\
\hline $\begin{array}{l}\text { NDVI }(705, \\
750)\end{array}$ & $\begin{array}{c}Y=135,6 x- \\
51,12\end{array}$ & 0.821 & 0.906 \\
\hline $\begin{array}{c}\text { RDVI (705, } \\
750)\end{array}$ & $\begin{array}{c}\mathrm{Y}=198,0 \mathrm{x}- \\
3,531\end{array}$ & 0,541 & 0.735 \\
\hline
\end{tabular}

\section{B. Peta Kerapatan Vegetasi}

Sasaran akhir dari penyusunan algoritma ini adalah pembuatan peta kerapatan vegetasi pada hutan gambut di Kalimantan Tengah dengan menggunakan algoritma terbaik yang telah dibentuk. Peta ini merupakan gambaran secara spasial pada daerah studi. Dalam peta distibusi crown cover ini wilayah terpetakan adalah lahan hutan gambut daerah studi yang terbagi menjadi 2 site. Permbuatan peta ini sebagai alat informasi untuk keberadaan vegetasi pada hutan gambut.

Tabel 2. Kelas Kerapatan Crown Cover ( Brack, Chris.

\begin{tabular}{ccc} 
& 1999 ) & \\
\hline Symbol & Description & Crown Cover Range \\
\hline 6 & Sangat Rapat & $85-100 \%$ \\
5 & Rapat & $70-84 \%$ \\
4 & Sedang & $50-69 \%$ \\
2 & Rendah & $30-49 \%$ \\
1 & Jarang & $10-29 \%$ \\
& Sangat Jarang & $1-9 \%$
\end{tabular}



Gambar 7. Peta Kerapatan Vegetasi Test Site 1 pada Hutan Gambut Kalimantan Tengah

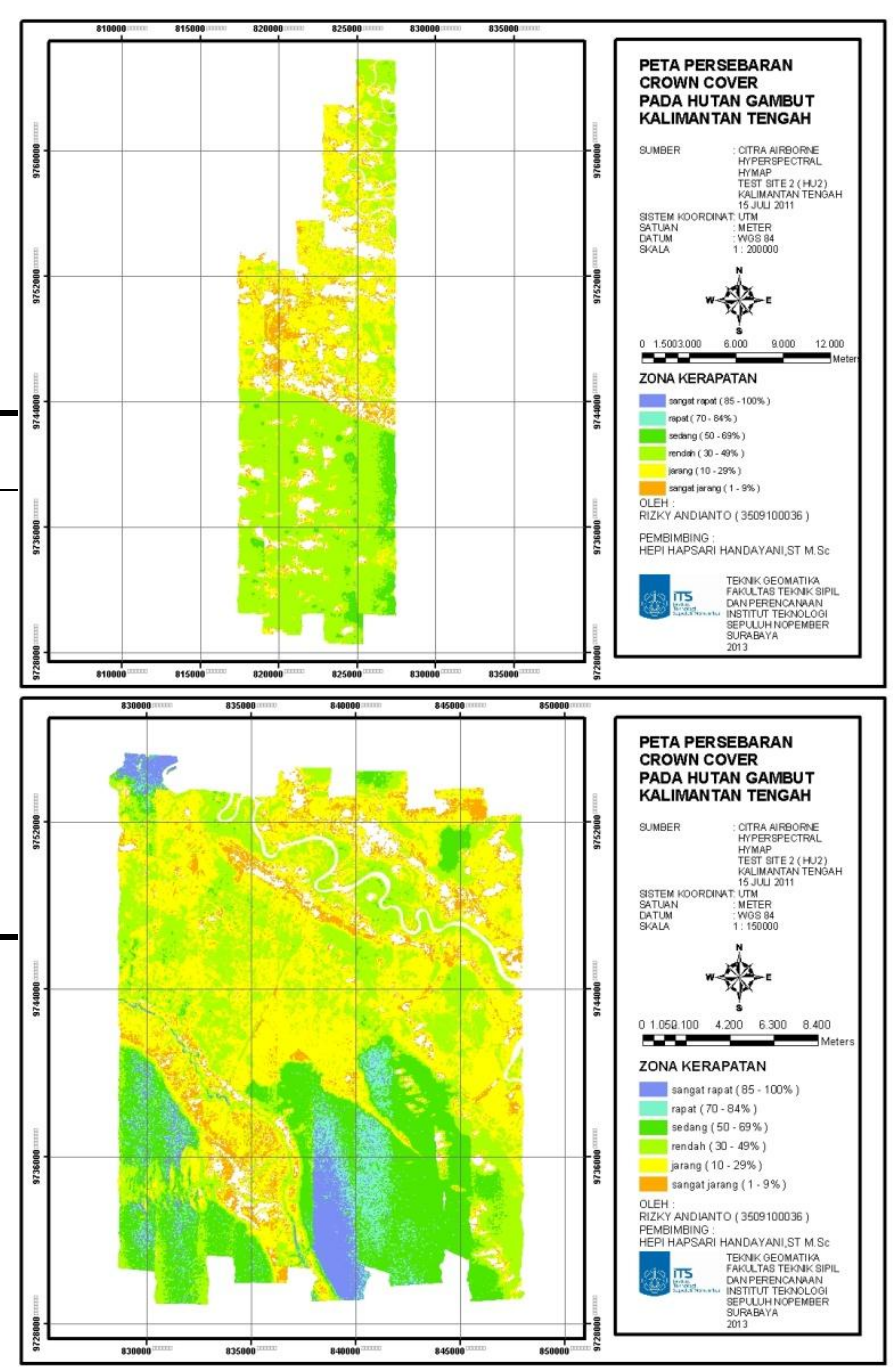

Gambar 8. Peta Kerapatan Vegetasi Test Site 2 pada Hutan Gambut Kalimantan Tengah 
Pada test site 1, luas tiap kelas zona kerapatan adalah sebagai berikut :

Tabel 3. Luas Tiap Kelas Zona Kerapatan pada Test Site 1 ( HU1 )

\begin{tabular}{cc}
\hline \hline Zona Kerapatan & Luas $\left(\mathrm{km}^{2}\right)$ \\
\hline Kerapatan Sangat Jarang & 20,474413 \\
Kerapatan Jarang & 60,067358 \\
Kerapatan rendah & 164,187069 \\
Kerapatan sedang & 25,934328 \\
Kerapatan rapat & 2,221723 \\
Kerapatan sangat rapat & 0,754286 \\
\hline \hline
\end{tabular}

Sedangkan pada test site 2, luas tiap kelas zona kerapatannya adalah sebagai berikut :

Tabel 4. Luas Tiap Kelas Zona Kerapatan pada Test Site 2 Lajur 1-5 ( HU2 )

\begin{tabular}{cc}
\hline \hline Zona Kerapatan & Luas $\left(\mathrm{km}^{2}\right)$ \\
\hline Kerapatan Sangat Jarang & 29,749719 \\
Kerapatan rendah & 58,830211 \\
Kerapatan sedang & 106,468601 \\
Kerapatan rapat & 3,347754 \\
Kerapatan sangat rapat & 0,020462 \\
\hline \hline
\end{tabular}

Tabel 5. Luas Tiap Kelas Zona Kerapatan pada Test Site 2 Lajur 7-16 ( HU2 )

\begin{tabular}{cc}
\hline Zona Kerapatan & Luas $\left(\mathrm{km}^{2}\right)$ \\
\hline \hline Kerapatan Sangat Jarang Jarang & 62,785975 \\
Kerapatan rendah & 149,419206 \\
Kerapatan sedang & 88,530619 \\
Kerapatan rapat & 73,061331 \\
Kerapatan sangat rapat & 9,429049 \\
\hline \hline
\end{tabular}

\section{ANALISA}

Untuk menganalisa perbedaan antar nilai indeks vegetasi digunakan metode analisa regresi antara nilai indeks vegetasi dengan data persentase crown cover. Indeks vegetasi yang digunakan pada penelitian ini adalah NDVI, RDVI, dan MSR dan menggunakan panjang gelombang $705-750$ $\mathrm{nm}$ dan $670-800 \mathrm{~nm}$. Namun untuk MSR hanya menggunakan panjang gelombang $705-750 \mathrm{~nm}$.

Dari hasil korelasi antara indeks vegetasi dan klorofil tanaman padi, Nilai indeks vegetasi NDVI pada panjang gelombang 750 - $705 \mathrm{~nm}$ lebih besar dibandingkan pada panjang gelombang 800 - $670 \mathrm{~nm}$. Ini dapat disebabkan karena nilai absorbansi maksimum dan nilai reflektan maksimum pada panjang gelombang $750 \mathrm{~nm}$ dan $705 \mathrm{~nm}$ terletak pada derivative pertama daripada pada panjang gelombang $800 \mathrm{~nm}$ dan $670 \mathrm{~nm}$. Data reflektan derivatif dapat memberikan nilai reflektan yang lebih representatif pada obyeknya daripada reflektan aslinya, karena reflektan derivatif dapat menghilangkan pengaruh dari faktor-faktor obyek sekitarnya ${ }^{[8]}$. Namun pada RDVI nilai pada panjang gelombang 750 - 705 lebih kecil dibandingkan pada panjang gelombang $800-670$.Nilai korelasi positif didapat dari kelima persamaan yang dihasilkan dari hasil regresi menunjukkan bahwa citra Hymap mampu digunakan dalam analisa indeks vegetasi hutan gambut karena persamaan tersebut menunjukkan adanya hubungan antara nilai indeks vegetasi yang diperoleh dari citra Hymap dengan prosentase crown cover yang berarti adalah prosentase dari tegakan vegetasi itu sendiri.

Berdasarkan dari nilai koefisien determinasi yang dihasilkan dari kelima indeks vegetasi, maka indeks vegetasi NDVI memiliki keakurasian yang paling baik terhadap data crown cover. Ini disebabkan karena untuk indeks vegetasi MSR dan RDVI merupakan indeks vegetasi yang dikembangkan untuk mengatasi masalah seperti lapisan yang banyak pada kanopi dan hubungan non linier terhadap parameter biofisik pada vegetasi secara spesifik khususnya pada hutan gambut yang memiliki beragam varietas. Dan jika dibandingkan dengan NDVI, Indeks simple ratio lebih dipengaruhi oleh faktor lingkungan seperti 
awan dan $\operatorname{tanah}^{[8]}$. Dan NDVI lebih cenderung pada struktur sel daun daripada $\mathrm{MSR}^{[8]}$. Namun dalam penelitian ini, MSR juga mempunyai hubungan data yang kuat dengan data crown cover. Hal ini dapat disebabkan nilai MSR ini menggunakan panjang gelombang $705 \mathrm{~nm}$ dan $750 \mathrm{~nm}$ sehingga mempunyai nilai diferensiasi yang lebih tampak.

Pada penelitian sebelumnya yang dilakukan oleh Purwana Edita Yudia pada tahun 2000 dengan menggunakan data Landsat TM pada ssebagian areal hutan gambut di Kalimantan Tengah dengan menggunakan algoritma NDVI, RVI, GVI, WVI, dan $\mathrm{BVI}^{[5]}$. Pada penelitian tersebut semua indeks vegetasi berpengaruh baik terhadap canopy cover kecuali BVI, dan pada NDVI juga sangat berpengaruh baik dengan koefisien determinasi > 0.80. Namun pada penelitian tersebut NDVI mempunyai koefisien determinasi yang lebih besar.

Pada penelitian ini, vegetasi yang teridentifikasi atau yang dihasilkan dari algoritma indeks vegetasi yang dgunakan akan dilakukan evaluasi dengan peraturan atau Undang - undang yang terkait. Peta kerapatan vegetasi yang dihasilkan akan dioverlaykan dengan Peta "Arahan Indikatif RKTN 2011 - 2030 Pulau Kalimantan" sesuai dengan UU RKTN Tahun 2011. Sebelum dilakukan overlay, Peta "Arahan Indikatif RKTN 2011 - 2030 Pulau Kalimantan" terlebih dahulu dilakukan proses georeferencing.

Kelas kerapatan vegetasi yang digunakan untuk evaluasi ini adalah kelas kerapatan sangat rapat $(85-100 \%)$, rapat $(70-84 \%)$, sedang $(50-69 \%)$, dan rendah (30 - 49\%). Untuk kelas kerapatan jarang dan sangat jarang tidak digunakan karena kelas tersebut belum mewakili adanya objek vegetasi.

Hasilnya adalah vegetasi pada test site 1 yang terletak di Kabupaten Katingan termasuk dalam 3 kawasan arahan kebijakan, yaitu sebagian kawasan konservasi, sebagian kawasan hutan alam dan lahan gambut, dan sebagian termasuk dalam kawasan perusahaan skala besar.
Lalu hasil pada vegetasi test site 2 yang terletak di Kabupaten Pulang Pisau termasuk dalam kawasan arahan kebijakan kawasan konservasi.

Hasil evaluasi terhadap Arahan Indikatif RKTN 2011 - 2030 adalah Pada test site 1 terdapat $0.002 \%$ dari vegetasi yang termasuk dalam kawasan hutan alam dan lahan gambut, $0.067 \%$ termasuk dalam kawasan pengusahaan kecil, dan 2.883\% termasuk dalam kawasan perusahaan skala besar (HA/HT). Namun pada test site $284 \%$ vegetasi termasuk pada dalam kawasan arahan kebijakan. Ini menunjukkan bahwa adanya hutan gambut di Kalimantan Tengah yang tidak termasuk pada kawasan hutan alam dan lahan gambut. Sehingga diperlukan adanya evaluasi yang lebih lanjut tentang kesesuaian kawasan arahan kebijakan UU RKTN tahun 2011.

\section{KESIMPULAN dan SARAN}

Dari penelitian ini dapat diambil beberapa kesimpulan, yaitu:

1. Indeks Vegetasi NDVI pada panjang gelombang 705 - $750 \mathrm{~nm}$ menghasilkan hubungan korelasi yang paling baik yaitu sebesar 0.906 .

2. Kelas presentase kerapatan vegetasi yang dihasilkan adalah sebanyak 6 kelas yang terdiri dari kelas sangat rapat ( NDVI : 0.995 1.114), rapat ( NDVI: $0.885-0.996)$, sedang ( NDVI : $0.772-0.886$ ), rendah ( NDVI: $0.657-$ 0.771), jarang ( NDVI: $0.542-0.656)$, dan sangat jarang ( NDVI: $0.384-0.541$ ). Kelas prosentase kerapatan vegetasi yang paling dominan adalah kelas dengan zona kerapatan rendah pada test site 1 dan test site 2 pada lajur 1-5 dan zona kerapatan jarang pada test site 2 lajur 7-16. Sedangkan kelas dengan prosentase persebaran yang paling rendah adalah kelas zona kerapatan sangat rapat pada kedua test site.

3. Rentang nilai NDVI pada panjang gelombang $(670,800) \mathrm{nm}$ pada citra Hymap test site 1 adalah $-0.750--0.909$, pada test site 2 lajur 15 adalah $(-0.442-0.997)$, pada test site 2 lajur 7-16 adalah (-0.348 - 0.947). NDVI pada panjang gelombang $(705,750) \mathrm{nm}$ pada citra Hymap test site 1 adalah $(-0.835-0.514)$, pada test site 2 lajur 1-5 adalah (-0.340 - 
0.996), pada test site 2 lajur 7-16 adalah (0.635 - 0.963). Rentang nilai RDVI pada panjang gelombang $(670,800) \mathrm{nm}$ pada citra Hymap test site 1 adalah (-0.651-0.976), pada test site 2 lajur 1-5 adalah (-0.270 - 0.775), pada test site 2 lajur 7-16 adalah (-0.382 0.978). sedangkan pada panjang gelombang $(705,750) \mathrm{nm}$ pada citra Hymap test site 1 adalah (-0.251-0.591), pada test site 2 lajur 15 adalah (-0.251-0.591), pada test site 2 lajur 7-16 adalah (-0.242-0.909). Dan rentang nilai MSR pada panjang gelombang $(705,750) \mathrm{nm}$ pada citra Hymap test site 1 adalah (-0.8250.853 ), pada test site 2 lajur 1-5 adalah (0.415- 0.925), pada test site 2 lajur 7-16 adalah (-0.740-0.909).

4. Hasil evaluasi terhadap Arahan Indikatif RKTN 2011 - 2030 adalah Pada test site 1 terdapat $40 \%$ dari vegetasi yang termasuk dalam kawasan hutan alam dan lahan gambut, 50\% termasuk dalam kawasan konservasi, dan $10 \%$ termasuk dalam kawasan perusahaan skala besar (HA/HT). Namun pada test site $250 \%$ vegetasi termasuk pada kawasan konservasi dan sisanya tidak termasuk dalam kawasan arahan kebijakan. Ini menunjukkan bahwa adanya hutan gambut di Kalimantan Tengah yang tidak termasuk pada kawasan hutan alam dan lahan gambut. Sehingga diperlukan adanya evaluasi yang lebih lanjut tentang kesesuaian kawasan arahan kebijakan UU RKTN tahun 2011.

\section{DAFTAR PUSTAKA}

Avery, T.E. and Burkhart, H.E. 2002. Forest Measurements. 5th edition. McGraw Hill, New York. $456 \mathrm{p}$

Brack, Chris. 1999. Crown Closure. ANU

Haboudane,Driss John R. Miller, Elizabeth Pattey, Pablo J. Zarco-Tejada, Ian B. Strachan.

Liang, S., T. Zheng, D. Wang, K. Wang, R. Liu, S. Tsay, S. Running, \& J. Townshend. 2007. " Mapping HighResolution on Interpreting Tower-Based Flux Observations". Remote Sensing of environment, 112, 337-349.

Purwana, Edita Yudia. 2000. Studi indeks vegetasi untuk identifikasi vegetasi hutan rawa gambut melalui analisis digital data landsat TM :: Studi kasus di sebagian areal HPH PT. Brata Jaya Utama, Kalimantan Tengah. Universitas Gadjah Mada, 2000

Takahashi, O. Takeda, T. Evri, M. Kashimura, O. Osaki, M. Hirose, K. Segah H. 2012. Quantitative Measurement from Unifying Field and Airborne Hyperspectral (HyMap) for Diagnosing Peat Forest Degradation in Central Kalimantan, Indonesia. Presented on "International Conference on Sustainability Study (ICSS)", Bali, January 11, 2012

Spur, S.H. 1952. Forest Inventory Ronald Press, New York. $476 p$.

Sukmono, Abdi. 2012. Algoritma Estimasi Kandungan Klorofil Tanaman Padi Dengan Data Airborne Hypersectral. Surabaya. Institut Teknologi Sepuluh Nopember

Peraturan Menteri Kehutanan Republik Indonesia Nomor : P.49/Menhut-li/2011 